\title{
HIP LUXATION AND ITS MANIFESTATIONS \\ ON A PELVIS OF A MAN FROM THE EARLY BRONZE AGE FROM LUDANICE-MÝTNA NOVÁ VES ${ }^{1}$
}

FROM LUDANICE-MÝTNA NOVÁ VES 1

\author{
Július Jakab - Jozef Bátora
}

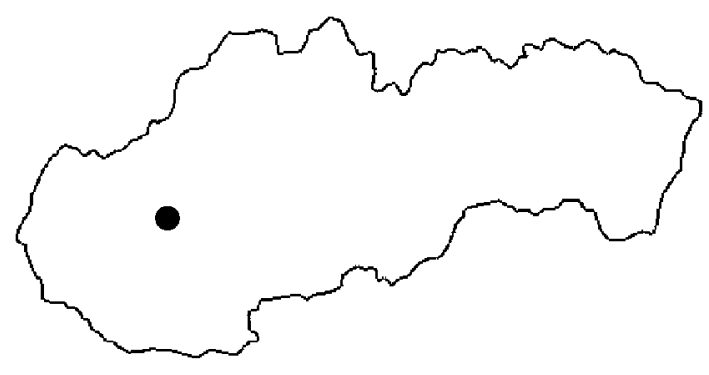

DOI: https://doi.org/10.31577/szausav.2020.67.9

Keywords: Early Bronze Age, neo-acetabulum, hip luxation, Slovakia

The paper presents an exceptional skeletal material bearing an implicit information on diseases and living conditions of the Early Bronze Age society in the territory of present-day Slovakia. Archaeological research in Ludanice-Mýtna Nová Ves, performed by the Institute of Archaeology of the Slovak Academy of Sciences in Nitra under the supervision of Jozef Bátora, revealed the cemetery that had been used by two consecutive Early Bronze Age populations of the Nitra and the Únětice cultures (2200-1900 cal. BC). A total of 606 graves were examined. Skeletal remains buried in Grave 501 were different from others: unusual bone changes were observed in the skeleton, especially as regards the bony socket for the femoral head of the dislocated left femur. The socket was located at the posterior side of the ilium, suggesting development of neo-acetabulum. The finding represents the first paleopathological case of its kind from prehistoric Slovakia, its uniqueness lying in providing new information about health status, living conditions, as well as interpersonal relationships in Early Bronze Age populations.

\section{INTRODUCTION}

According to some experts (e.g., Okawa et al. 2018), neo-acetabulum is an artificial joint created at the site of the original acetabulum. According to others (e.g., Wakely 1993), any depression in the ilium serving as a substitute of a joint socket, located on the lateral side of the bone above the original acetabulum, can be considered as neo-acetabulum. In the latter case, neo-acetabulum is only formed when the femoral head fully slips out of the original acetabulum and permanently rubs against the ilium (ala ossis ilii) while walking.

In a healthy person, acetabulum represents the joint socket of the ilium. Via femoral head, it joins the torso with the lower limb. The dislocation of the hip may be congenital, but may also occur as a result of an injury. Nowadays, most congenital hip dislocations are treated shortly after birth, post-traumatic luxations being treated immediately after the injury. Congenital dislocation requires the cooperation of a paediatrician and an orthopaedic surgeon, and post-traumatic dislocation presupposes the collaboration of a traumatologist and an orthopaedic surgeon. In modern civilised world, every post-traumatic dislocation is diagnosed in time, repositioned and treated. Non-repositioned post-traumatic dislocation is usually accompanied by excessive bone remodelling, often by arthritis, and rarely also by infection. In modern population, no traumatologist or orthopaedic surgeon can come across a case of an additional bony socket for the femoral head located outside the original acetabulum.

\section{MATERIAL AND METHODS}

Archaeological research in Ludanice-Mýtna Nová Ves (Topol’čany district) in southwestern Slovakia was performed by the Institute of Archaeology of the Slovak Academy of Sciences in Nitra, under the supervision of J. Bátora (from 1982 to 1989 and in 2003 and 2014; Bátora 1991; Bátora/Schultz 2004; 2019).

1 The study was realised within the VEGA projects no. 2/0001/18 'Slovakia and the Middle Danube Region: development from the Early history to the Early Middle Ages' and 1/0100/19 'Economy and society in the Bronze Age in the area of middle Danube according to archaeological and environmental data' and as a sustainability impact indicator of the project ITMS: 26220120059. 


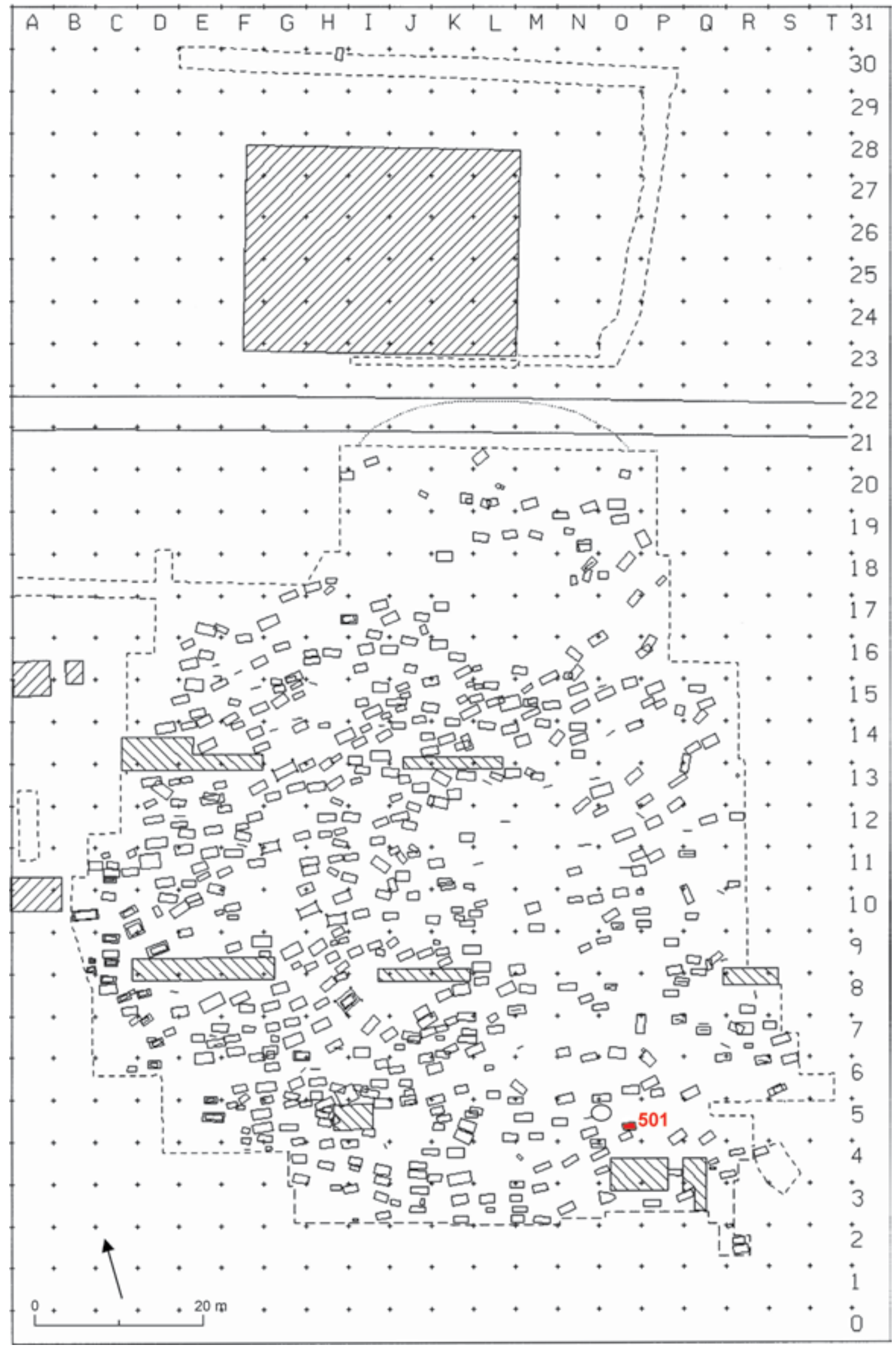

Fig. 1. Ludanice-Mýtna Nová Ves (Topoľčany district). Ground plan of the Early Bronze Age cemetery and the location of the grave 501/89 within the cemetery. 


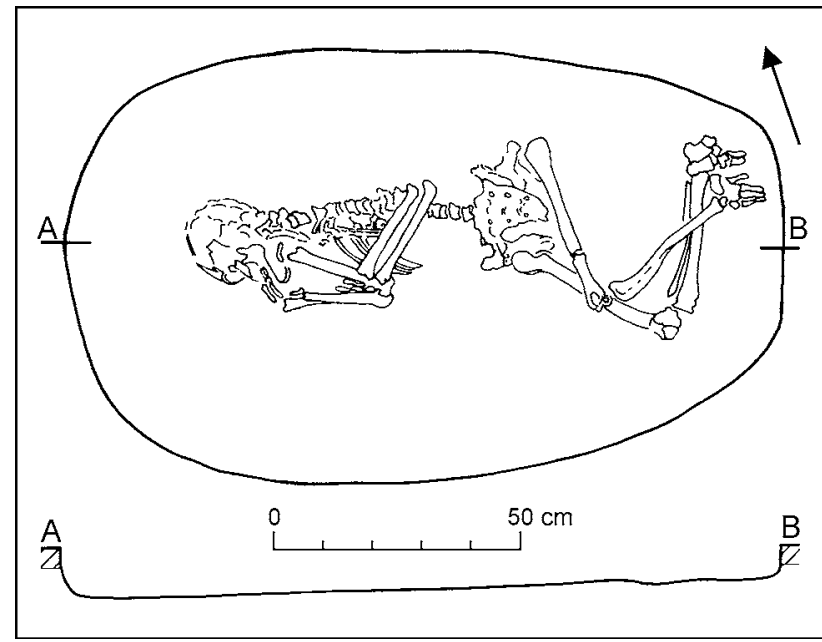

Fig. 2. Ludanice-Mýtna Nová Ves (Topoľčany district). Ground plan of the grave 501/89.

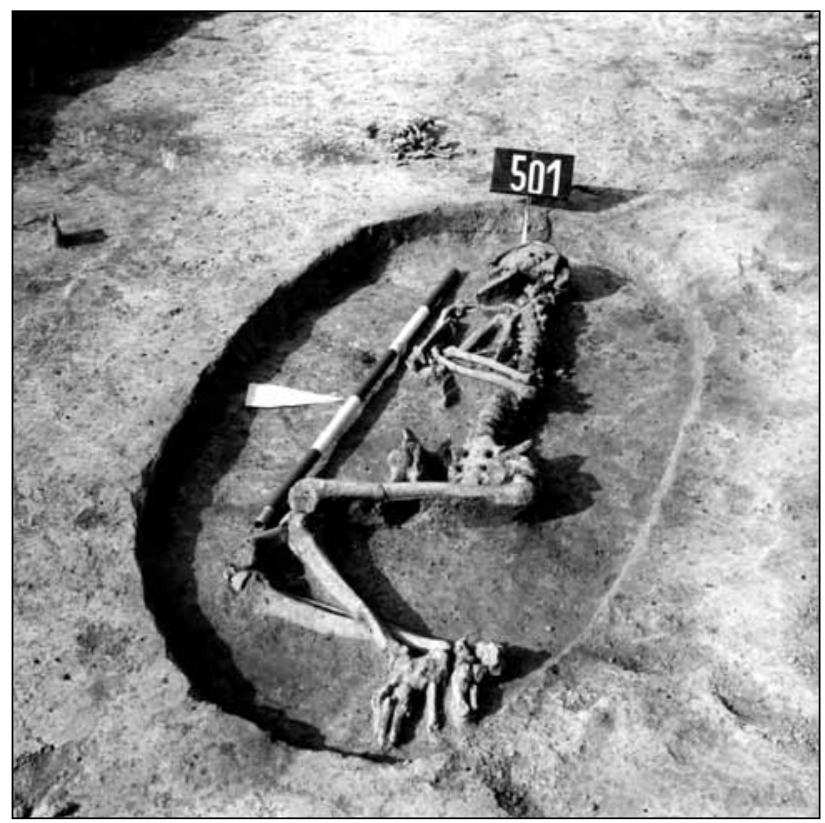

Fig. 3. Ludanice-Mýtna Nová Ves (Topolčany district). Photograph of the grave 501/89 (Archive of the Institute of Archaeology SAS in Nitra. Photo J. Bátora.
The cemetery had been used by two consecutive populations of the Nitra and the Únětice cultures (2200-1900 cal. BC), and a total of 606 graves were examined. Grave 501 was located in the south-eastern part of the cemetery (Fig. 1). The grave pit showed as an oval spot of pale brown colour. Excavation revealed that the corners of the pit were rounded, the walls slightly sloped and the bottom slanting westwards. Dimensions of the grave pit were following: length $-144 \mathrm{~cm}$, width $-87 \mathrm{~cm}$ and depth $-6-10 \mathrm{~cm}$ (Fig. 2; 3). At the bottom of the pit lay a skeleton of an adult. The individual had been placed on the right side, oriented in west-east direction, face to the southsouthwest. Upper limbs were bent, the right limb being bent at an acute angle, with hand close to the mandible. The bones of the left upper limb lay on the top of those of the right extremity. The long bones of the lower limbs were partially overlapping and were bent at $70^{\circ}$ angle. The grave contained no equipment.

Neither the location of the grave nor the position of the skeleton were different from other graves at the site. Owing to the absence of grave inventory, no precise cultural affiliation could be made, even though some clues were provided by the inventory of eleven nearby graves located within a radius of up to $5 \mathrm{~m}$. In three graves, no inventory was found, four graves contained only earrings and lockrings made of simple or multiple-times twisted copper wire (of these, two graves contained also bone awls), and in two graves only beads from an antler necklace were found. However, two graves yielded chronologically relevant findings: in addition to antler beads, Grave 361 contained three willow-leaf-shaped earrings with a narrow leaf and no distinct midrib, indicating older phase of the Nitra culture (Bátora 2000); in Grave 503, a copper hatchet of so called Saxon type (with no edge strips) was discovered, associable either with final Nitra-Únětician phase of the Nitra culture or with the early Únětician phase of the Únětice culture. In addition, most of the above-men-

tioned graves included inventory associated with the final Nitra-Únětician phase of the Nitra culture (BA1c). In the light of these circumstances, Grave 501 can most probably be also dated to the same period.

From Grave 501, only eroded and highly damaged bones of postcranial skeleton were available for anthropological analysis (the damage was probably caused by a plough, as indicated by the fact that the skeleton lay in a shallow grave located at the boundary between the topsoil and the loess subsoil). The age at death and the sex of the individual were estimated by the methods suggested by Nemeskéri/ Harsányi/Acsádi 1960, Acsádi/Nemeskéri 1970, and Ferembach/Schwidetzky/Stloukal 1979. Skeletal anomalies and abnormal changes were also evaluated.

Alas, palaeopathological analyses of archaeological skeletal remains (macroscopic, microscopic and histological) in Slovakia are scarce, as there is no institution employing a full-time palaeopathologist. 
The diagnosis of pathological changes observed on the skeleton from grave 501 was therefore estimated by a physician, prim. MUDr. J. Kayser, the head of the Orthopaedic-traumatology department of the Hospital of St. Luke in Galanta. Only macroscopic analysis and X-ray imaging were employed. Complex palaeopathological analysis was not performed despite the fact that such a unique finding would highly benefit from detailed interdisciplinary research including the participation of an archaeologist, anthropologist, traumatologist, orthopaedist and palaeopathologist.

\section{DESCRIPTION OF SKELETAL CHANGES AND DIAGNOSIS}

Skeletal changes indicating hip luxation were revealed by osteological analysis of the skeletal remains from Grave 501 the Early Bronze Age cemetery at Ludanice-Mýtna Nová Ves. As stated earlier in the article, pathological changes were diagnosed by prim. MUDr. J. Kayser, suggesting the case of neoacetabulum:

"Today, in newborn babies, diagnosed with hip dysplasia, so called 'wide swaddling' is applied. In the neoacetabulum of the skeleton from Grave 501 from Ludanice-Mýtna Nová Ves, neither valgus nor the anteversion of the left femoral neck were observed. This case hence does not represent a dislocation of congenital but rather of posttraumatic aetiology. The current condition is a result of a non-repositioned traumatic hip dislocation at a younger age. The head of the left femur had shifted out of the acetabulum, backwards, to the posterior side of the ilium, and was then moving cranially. As a part of a healing process, a new socket was formed around the femoral head, then the socket ossified. The man practically didn't use his left leg. Walking was probably very limited and must have been very painful. There are also advanced arthritic changes on the inner surface of the neo-acetabulum and on the left femoral head. As a result, the left leg got into a so called 'gamma-position'. In other words, an adduction and intrarotation of the thigh occurred, as did the extra-rotation of the knee."

(J. Kayser, personal communication).

To summarise, after traumatic dislocation of the left leg at a younger age, the head of the femur slowly moved to the posterior of the ilium. However, instead of neo-acetabulum represented by a depression on the posterior side of the ilium, a socket was formed around the femoral head. In a time, the socket ossified and unified with the ilium. The socket has its own structure and is about 1-18 mm thick (Fig. 4-7). Its upper margin is situated about $76 \mathrm{~mm}$ above the upper edge of the original acetabulum. The new socket was firmly attached to the ilium (ala ossis ilii), of which only a small part, with almost complete auricular surface (facies auricularis), has been preserved. However, not even the newly formed socket, unified with the ilium, is complete. The outer surface of the preserved part of the socket is smooth, having an appearance of a 'callus', i. e. a new bone formation observed in healed displaced fractures of long limb bones (so called 'massive callus'). The thickness of the socket wall is not uniform either, being the greatest at the point where it is attached to the ilium (about $18 \mathrm{~mm}$ ) and the lowest at the dorsal part of the socket, about $20 \mathrm{~mm}$ above the lowest margin of the socket (about $1 \mathrm{~mm}$ ). The edges of the preserved portion of the ossified socket are not clearly determined, they are discontinuous and indistinct. The socket walls are thick, creating a 7-21 mm thick 'rim'. Both the dorsal and the caudal parts of the rim, as well as the socket, were broken off post-mortem, probably as a result of inappropriate removal of the skeleton from the grave. The diameter of the head of the femur is apparently larger than the diameter of the socket "entrance". As a result, the femoral head was probably difficult to remove from the newly formed socket, and was probably pried open from the case. The broken-off bone fragments were not preserved for the analysis. The original shape of the socket opening is believed to be oval, with vertical (cranio-caudal) parameter being about $58 \mathrm{~mm}$, horizontal (anterio-posterior) parameter being estimated to only about $46 \mathrm{~mm}$. The maximum diameter of the socket cavity is approximately $63 \mathrm{~mm}$. The heads of both femurs are of expected, approximately hemispherical shape, having almost ideal circular shape of the circumference. The diameter of the right head is about $50 \mathrm{~mm}$, the diameter of the left femoral head is about $55 \mathrm{~mm}$. The heights of the right and left femoral heads (direct distance from the limbus capitis femoris to the edge of the fovea capitis femoris) are about $45 \mathrm{~mm}$ and $47 \mathrm{~mm}$ respectively. The head of the left femur manifests apparent arthritic changes (Schultz 1988). In addition, the inner surface of the socket is rippled, probably due to chronic inflammation. The head of the affected femur is more flattened than the head of the right "healthy" femur or an average femur (Bodoriková et al. 2014; Horáčková et al. 2004). Socalled 'adaptive osteophyte' had been formed at the crista intertrochanterica of the affected femur (being about $14 \times 26 \mathrm{~mm}$ at the base; with the maximum height of about $14 \mathrm{~mm}$ ). 


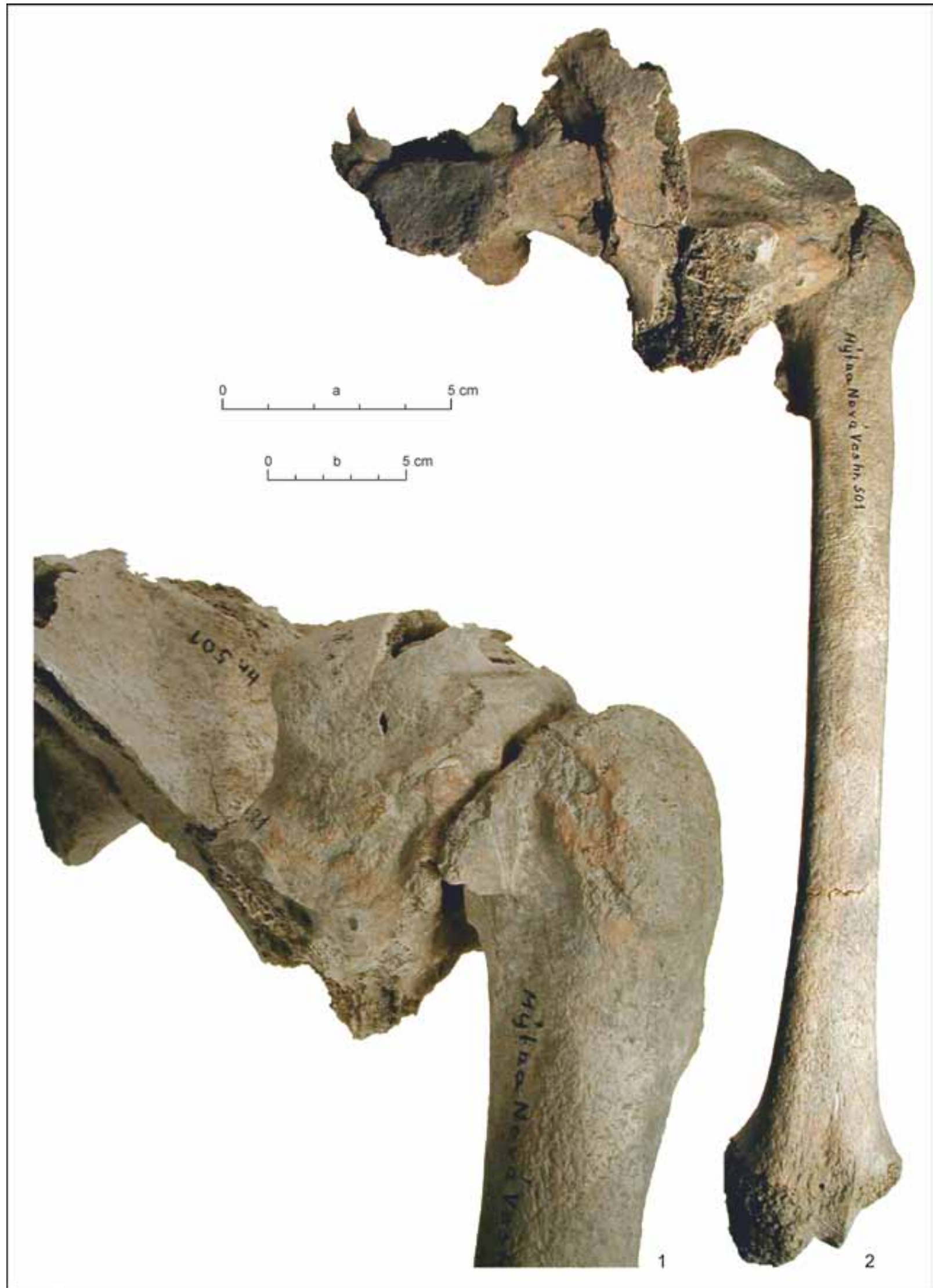

Fig. 4. Ludanice, a local part of Mýtna Nová Ves, grave 501/89 - man, maturus II. 1 - detail of the "connection" of the so called adaptations osteophyt femurs with the ventral edge of "neoacetabulum"; 2 - preserved part of sacrum and hucklebone with "neoacetabulum" and femur in "sitting" position of the handicapped (view from the top). Scale: $a-1 ; b-2$. 


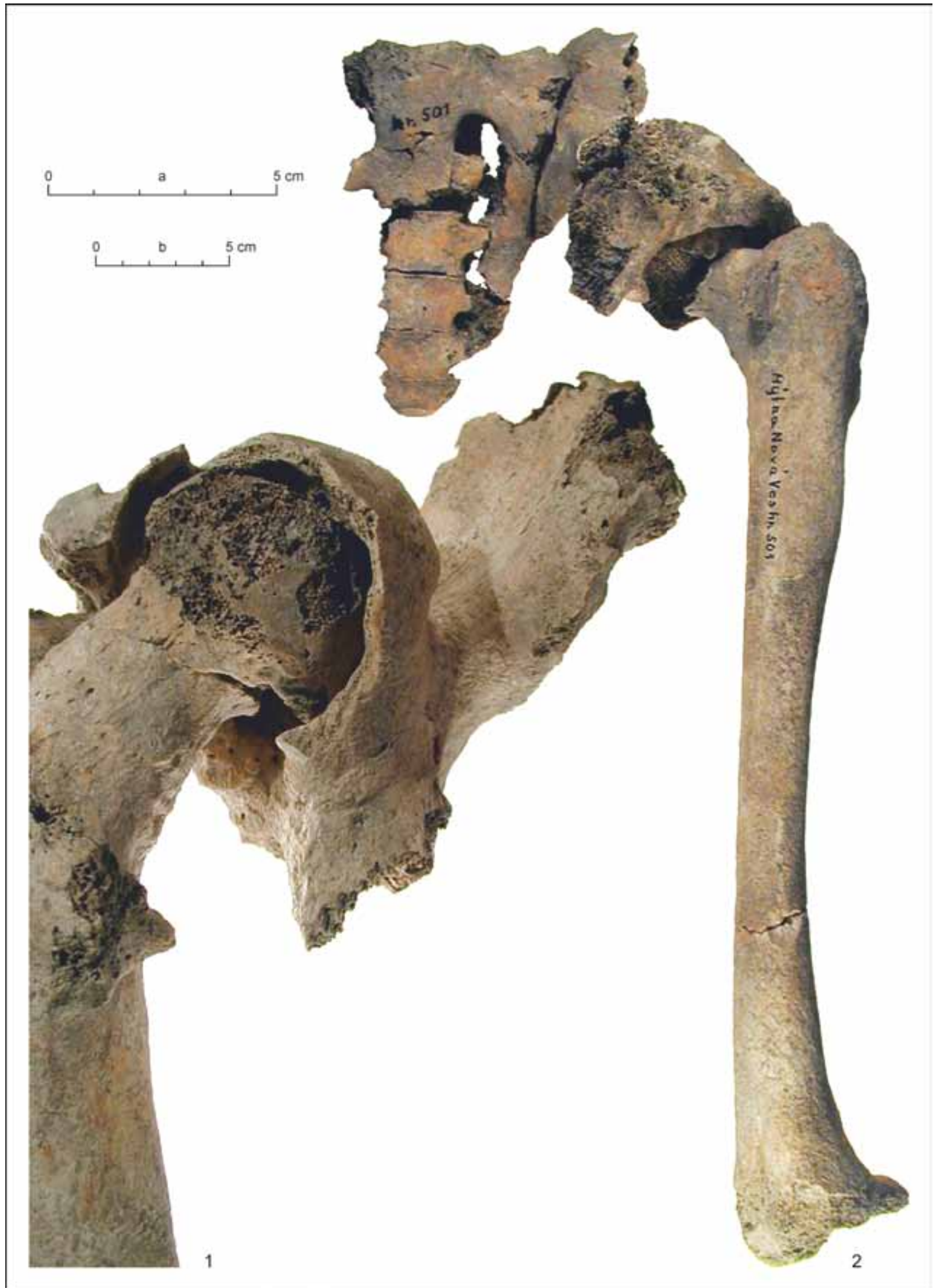

Fig. 5. Ludanice, a local part of Mýtna Nová Ves, grave 501/89 - man, maturus II. 1 - head of the femur in the damaged "neoacetabulum" (view from dorsal side); 2 - preserved part of sacrum and hucklebone with "neoacetabulum" and femur in position by standing of the handicapped (view from ventral side). Scale: $a-1 ; b-2$. 


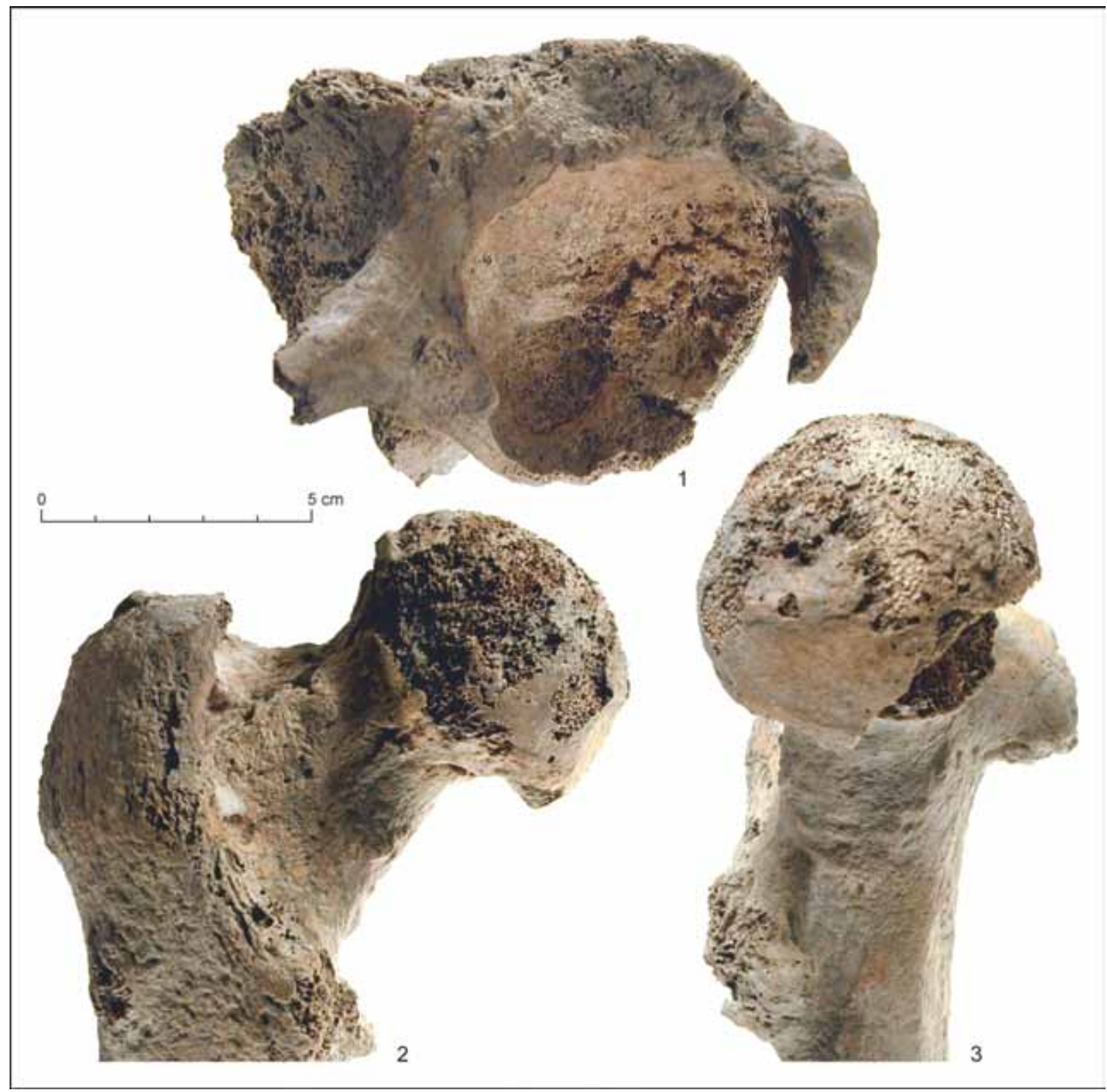

Fig. 6. Ludanice, a local part of Mýtna Nová Ves, grave 501/89 - man, maturus II. 1 - view on the circumference and part of the inner surface of "neoacetabulum"; 2 - head and cervix of the femur (view from dorsal side); 3 - head and cervix of the femur (view from medial side).

Movement must have been very painful and restricted for this man, it is very probable that he was sitting most of the time, practically not using his left leg at all. It is obvious that the affected man could not have taken care of his own livelihood (gather plants, harvest, hunt, etc.) or participate in fighting. It is very likely that he used a mechanical device to walk, as indicated by asymmetrical relief of muscle attachment sites, which is apparently more pronounced on the long bones of the right leg. Such a conclusion is also supported by X-ray imaging (Fig. 4).

\section{RESULTS}

From the skull, only four small and eroded fragments could be examined. The bones of the postcranial skeleton were rather robust, with moderate relief of muscle attachment sites observable on the better-preserved bones. 


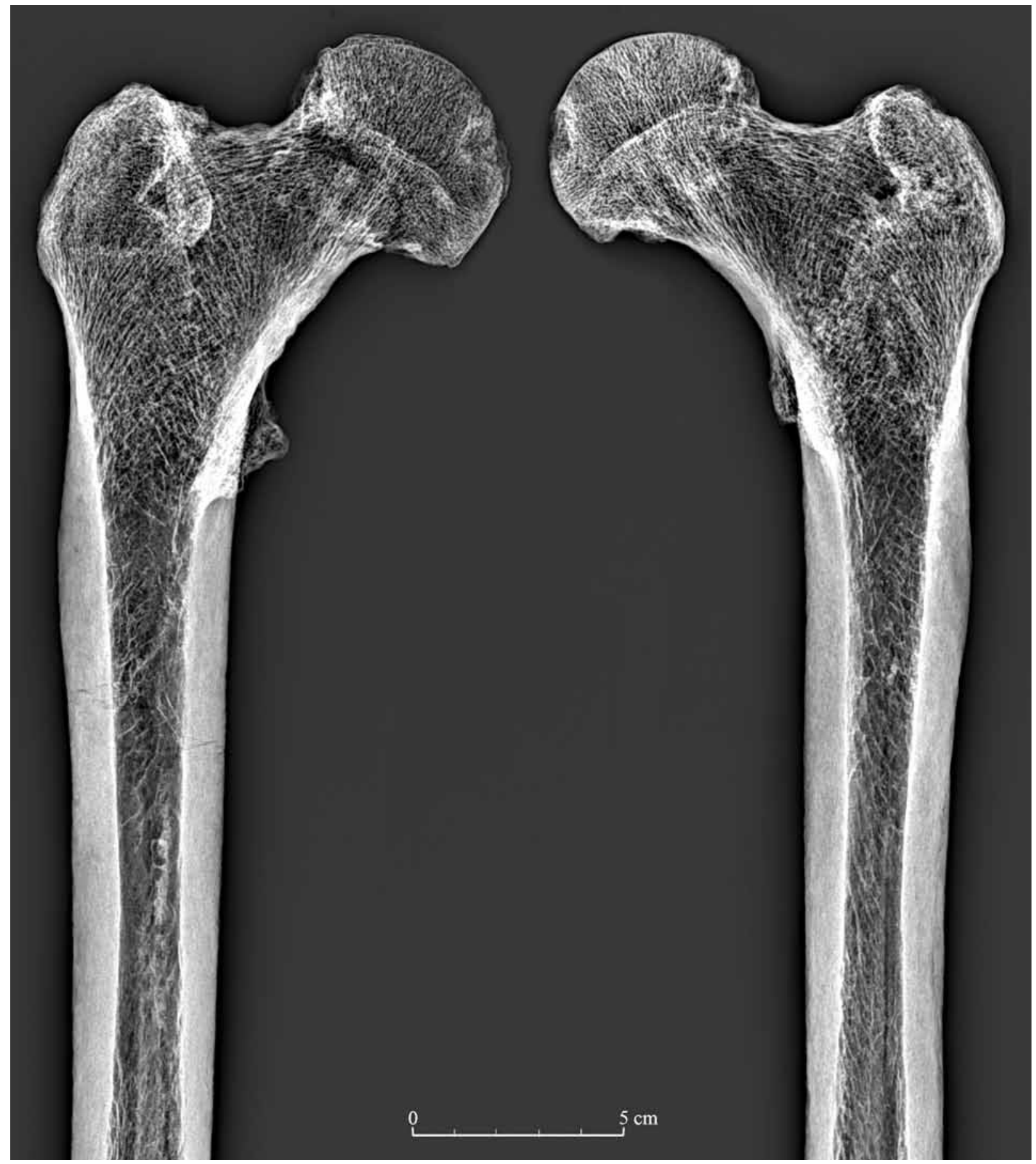

Fig. 7. Ludanice, a local part of Mýtna Nová Ves, grave 501/89 - man, maturus II. Anteroposterior sciagram from the proximal ending of femurs (right the right femur).

Sex-determining features typical for a male individual included the shape of the pelvic intlet, arc composè, os sacrum, femoral head and linea aspera; male rather than female individual was indicated also by the foramen obturatum, crista iliaca, iliac fossa, pelvis major, incisura ischiadica major, sulcus praeauricularis and corpus ossis ischii. The most severe pathological changes were recorded in the already mentioned left hip joint. Anthropological analysis indicated that the individual from the grave 501 was a male older than 50 years (maturus II). 


\section{CONCLUSION}

The paper presents another osteological case report (see also Jakab 2008; 2018). In addition to basic information about the finding, it also provides its exact description and suggested diagnosis. Anthropological analysis of the skeleton from Grave 501/89, a male older than 50 years, revealed unusual bone formation - a bony socket for the femoral head at the posterior side of the ilium, believed to be a neoacetabulum secondary to trauma.

On the basis of archaeological finds, the cemetery in Ludanice-Mýtna Nová Ves has been dated to the Early Bronze Age (Nitra and Únětice culture, Bátora 1991; 2018). In the Early Bronze Age, in the territory of present-day Slovakia, also men with significant physical disabilities lived potentially longer than 50 years, although the number of such cases is limited. A relatively small percentage of men from this geographical region lived so long (8 to $12 \%$, Jakab 2007). From 606 graves from Ludanice-Mýtna Nová Ves, only the presented case of unusual hip dislocation occurred. The fact that the man buried in Grave 501 had survived for so many years despite the significant health limitations indicates that there must have been a positive relationship between him and other members of the community. Whether this was due to close family relations or his extraordinary contribution to the community could not be evaluated. Based on contexts observed in other contemporary burial sites, where individuals with severe injuries also survived for a long time (e.g., a man from Grave 388 from Jelšovce; Bátora 2018, fig. 256), solidarity and high ethical behaviour of community members may also be considered. Similar behaviour may hence be presumed in the community from Ludanice-Mýtna Nová Ves, a population of an early stage of the Únětice culture.

For professional pathological evaluation of the skeletal remains from the Grave 501 from Ludanice Mýtná Nová Ves we thank MUDr. J. Kayser, the head of the Orthopaedic-traumatology department of the Hospital of St. Lukáša in Galanta.

Translated by Bc. Zuzana Hukelová, MSc., PhD.

\section{BIBLIOGRAPHY}

Acsádi/Nemeskéri 1970

Bátora 1991

Bátora 2000

Bátora 2018

Bátora/Schultz 2004

Bátora/Schultz 2019

Bodoriková et al. 2014

Ferembach/Schwidetzky/Stloukal 1979

Horáčková et al. 2004

Jakab 2007

Jakab 2008

Jakab 2018

Nemeskéri/Harsányi/Acsádi 1960

Okawa et al. 2018
Gy. Acsádi/J. Nemeskéri: History of Human Life Span and Mortality. Budapest 1970. J. Bátora: Záverečná sezóna záchranného výskumu v Ludaniciach v časti Mýtna Nová Ves. AVANS 1989, 1991, 23, 24.

J. Bátora: Das Gräberfeld von Jelšovce/Slowakei. Ein Beitrag zur Frühbronzezeit im nordwestlichen Karpatenbecken 2. Kiel 2000.

J. Bátora: Slovensko v staršej dobe bronzovej. Bratislava 2018.

J. Bátora/M. Schultz: Výskum pohrebiska zo staršej doby bronzovej v Ludaniciach. AVANS 2003, 2004, 29.

J. Bátora/M. Schultz: Pokračovanie výskumu na pohrebisku zo staršej doby bronzovej v Ludaniciach-Mýtnej Novej Vsi. AVANS 2014, 2019, 17, 18.

S. Bodoriková/K. Molnárová/R. Beňuš/I. Kvetánová/M. Slivka/M. Fuchsová/E. Neščáková: Analýza kostrových pozostatkov z okolia gotickej kaplnky pri zaniknutom Kostole sv. Kataríny v Dechticiach (okr. Trnava), exhumovaných v rokoch 2008, 2009 a 2011. Slovenská antropológia 17, 2014, 5-14.

D. Ferembach/I. Schwidetzky/M. Stloukal: Empfehlungen für die Alters- und Geschlechtsdiagnose am Skelett. Homo 30, 1979, 1-32.

L. Horáčková/E. Strouhal/L. Vargová 2004: Základy paleopatologie. In: J. Malina (ed.): Panoráma biologické a sociokulturní antropologie. Brno 2004, 263.

J. Jakab: Grundkennziffern der Paläodemographie der frühbronzezeitlicher Gräberfelder von Jelšovce. Slovenská archeológia 52, 2007, 277-283.

J. Jakab: Patologický otvor v čelusti muža zo staršej doby bronzovej v Jelšovciach (okres Nitra). Slovenská antropológia 11, 2008, 40-45.

J. Jakab: Rizomélia v slovenskom praveku a vo včasnej dobe dejinnej. Študijné zvesti AÚ SAV 64, 2018, 1-7.

J. Nemeskéri/L. Harsányi/Gy. Acsádi: Methoden zur Diagnose des Lebensalters von Skelettfunden. Anthropologischer Anzeiger 24, 1960, 70-95.

T. Okawa/P. C. Noble/S. K. Ismaily/M. T. Thompson/J. D. Johnston: A High Hip Center Limits Stable Joint Motion Following THR. Poster No 1338. http://onlinelibrary. wiley.com/doi/10.1002/oa.1390010311/pdf [7. 5. 2018]. 
Schultz 1988

Wakely 1993
M. Schultz: 6. Paläopathologische Diagnostik. Gelenkstatus. In: R. Knußmann (ed.): Anthropologie. Handbuch der vergleichenden Biologie des Menschen. Gustav Fischer Verlag. Stuttgart - New York 1988, 481-487.

J. Wakely: Bilateral Congenital Dislocation of the Hip, Spina Bifida occulta and Spondylolysis in a female skeleton from the Medieval Cemetery at Abingdon, England. Journal of Paleopathology 5, 1993, 37-45.

\title{
Luxácia bedrového kíbu a jej prejavy na panve muža zo staršej doby bronzovej z Ludaníc-Mýtnej Novej Vsi
}

\author{
Július Jakab-Jozef Bátora
}

\begin{abstract}
Súhrn
Príspevok informuje o neobvyklom kostnom novotvare, kostnom puzdre hlavice vykĺbenej lavej stehnovej kosti u staršieho muža z hrobu 501, na pohrebisku zo staršej doby bronzovej (2200-1900 cal. BC) v Ludaniciach, miestnej časti Mýtna Nová Ves.

Diagnózu patologických zmien na stehnových a panvových kostiach urobil lekár na základe makroskopického posúdenia nálezu a hodnotenia skiagramov.

Bedrový zhyb si muž vykíbil v mladosti a zomrel až vo veku maturus II (50-60 rokov). Nemohol sa postarat’ o svoju bezpečnost’ a nemohol ani lovit', zbierat’ plodiny, úrodu alebo zúčastňovat' sa bojov. Pohyb bol pre neho vel'mi bolestivý, väčšinou sedel a lavú nohu prakticky nepoužíval. Výnimočnost̉ nálezu spočíva v doložení nového poznatku, ktorý sa týka zdravotného stavu, životných podmienok, ale aj medziludských vztahov v populácii staršej doby bronzovej.
\end{abstract}

Obr. 1. Ludanice-Mýtna Nová Ves, (okr. Topolčany). Plán pohrebiska zo staršej doby bronzovej s vyznačením polohy hrobu 501/89.

Obr. 2. Ludanice-Mýtna Nová Ves, (okr. Topolčany). Plán hrobu 501/89.

Obr. 3. Ludanice-Mýtna Nová Ves, (okr. Topolčany). Fotografia hrobu 501/89 (archív AÚ SAV Nitra. Foto J. Bátora.

Obr. 4. Ludanice, miestna čast’ Mýtna Nová Ves, hrob 501 - muž, maturus II. 1 - detail „kontaktu“ tzv. adaptačného osteofytu stehnovej kosti s ventrálnym okrajom „neoacetábula“; 2 - zachovaná čast’ krížovej a bedrovej kosti s „neoacetábulom“ a stehnovou kostou v „sediacej“ polohe postihnutého (pohl'ad zhora). Mierka: a - 1; b-2.

Obr. 5. Ludanice, miestna čast’ Mýtna Nová Ves, hrob 501 - muž, maturus II. 1 - hlavica stehnovej kosti v poškodenom „neoacetábule“ (pohlad z dorzálnej strany); 2 - zachovaná čast’ krížovej a bedrovej kosti s „neoacetábulom“ a stehnovou kostou v polohe pri státí postihnutého (pohlad z ventrálnej strany). Mierka: $a-1 ; b-2$.

Obr. 6. Ludanice, miestna čast' Mýtna Nová Ves, hrob 501 - muž, maturus II. 1 - pohl'ad na obvod a čast̉ vnútorného povrchu „neoacetábula“; 2 - hlavica a kŕčok stehnovej kosti (pohlad z dorzálnej strany); 3 - hlavica a kŕčok stehnovej kosti (pohlad z mediálnej strany).

Obr. 7. Ludanice, miestna čast’ Mýtna Nová Ves, hrob 501 - muž, maturus II. Anteroposteriórny skiagram proximálneho konca femurov (vpravo pravý femur).

RNDr. Július Jakab, CSc.

Archeologický ústav SAV

Akademická 2

SK - 94921 Nitra

nraujaka@savba.sk prof. PhDr. Jozef Bátora, DrSc.

Archeologický ústav SAV

Akademická 2

SK - 94921 Nitra

nraubato@savba.sk 